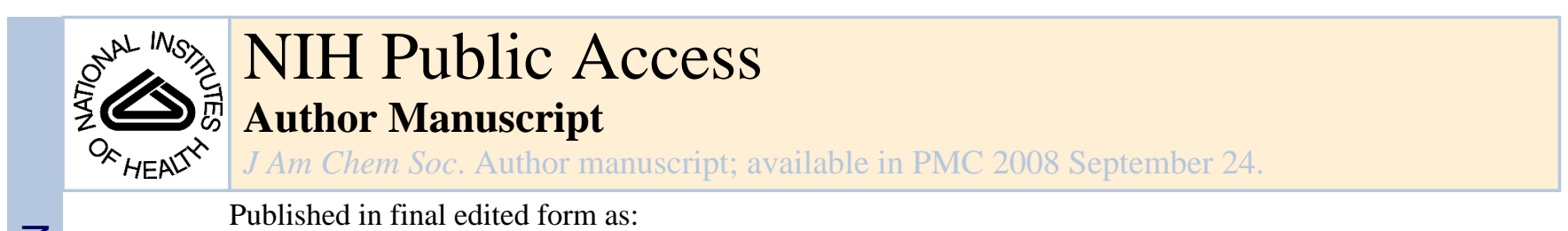

Published in final edited form as:

J Am Chem Soc. 2005 August 17; 127(32): 11212-11213. doi:10.1021/ja0520114.

\title{
Redox Couples of Inducible Nitric Oxide Synthase
}

\author{
Andrew K. Udit $\%$, Wendy Belliston-Bittner\&, Edith C. Glazer\&,\#, Yen Hoang Le Nguyen \&, \\ James M. Gillan $\%$, Michael G. Hill $\%$, Michael A. Marletta $\$$, David B. Goodin $\#$, and Harry B. \\ Gray ${ }^{*}{ }^{*}$ \\ \% Department of Chemistry, Occidental College, Los Angeles, CA 90041 \\ \& Division of Chemistry and Chemical Engineering, California Institute of Technology, Pasadena, CA 91125 \\ \# The Scripps Research Institute, La Jolla, CA 92037 \\ \$ Department of Chemistry, University of California, Berkeley, CA 94720
}

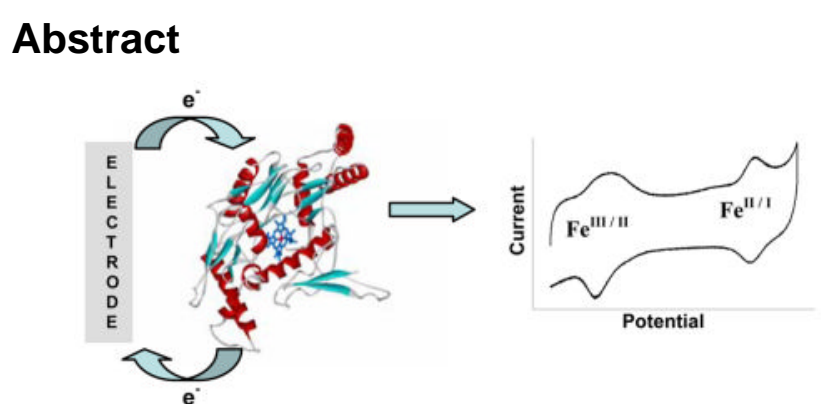

We report direct electrochemistry of the iNOS heme domain in a DDAB film on the surface of a basal plane graphite electrode. Cyclic voltammetry reveals $\mathrm{Fe}^{\mathrm{III} / \mathrm{II}}$ and $\mathrm{Fe}^{\mathrm{II} / \mathrm{I}}$ couples at -191 and $-1049 \mathrm{mV}$ (vs. $\mathrm{Ag} / \mathrm{AgCl}$ ). Added ligands imidazole and carbon monoxide shift the $\mathrm{Fe} \mathrm{e}^{\mathrm{III} / \mathrm{II}}$ potential by +20 and $+62 \mathrm{mV}$, while the addition of dioxygen results in large catalytic waves at the onset of $\mathrm{Fe}^{\mathrm{III}}$ reduction. Voltammetry at higher scan rates reveals that the $\mathrm{Fe}^{\mathrm{III} / \mathrm{II}}$ cathodic peak can be resolved into two components, which are attributable to $\mathrm{Fe} \mathrm{e}^{\mathrm{III} / \mathrm{II}}$ couples of 5- and 6-coordinate hemes. Digital simulation of our experimental data implicates water dissociation from the heme as a gating mechanism for ET in iNOS.

\footnotetext{
The critical role of nitric oxide (NO) in cellular signaling is firmly established. ${ }^{1}$ In higher animals, NO is synthesized by nitric oxide synthase (NOS), which converts L-arginine to citrulline and NO with NADPH and $\mathrm{O}_{2}$ as co-substrates. ${ }^{2}$ The enzyme consists of a reductase domain where electrons from NADPH are shuttled through bound flavins FAD and FMN, a calmodulin binding region that controls electron transfer (ET) to the heme, and a heme domain that contains a cysteine-ligated heme and tetrahydrobiopterin $\left(\mathrm{H}_{4} \mathrm{~B}\right)$. Investigations herein utilize the heme domain of inducible NOS (iNOS), an immune system isoform implicated in several diseases in humans. ${ }^{3}$

The complexity of NOS and its impact on human health have thrust work on the NOS mechanism into the spotlight. It is well established that the catalytic cycle involves two turnovers of the enzyme. The first turnover converts L-arginine to N-hydroxyarginine: although envisioned as a P450-like hydroxylation, the reaction is dependent on one-electron oxidation of $\mathrm{H}_{4} \mathrm{~B} .{ }^{4}$ The second turnover is thought to involve a ferric peroxide nucleophile,
} 
but $\mathrm{H}_{4} \mathrm{~B}$ is also required for this turnover in an as yet undetermined role. Although many details of the NOS mechanism remain to be elucidated, it is certain that ET reactions are key steps in the catalytic cycle.

Direct electrochemistry of iNOS can be achieved by confining the protein in didodecyldimethylammonium bromide (DDAB) films on the surface of basal plane graphite electrodes (BPG). ${ }^{5-7}$ We report reduction potentials for $\mathrm{Fe}^{\mathrm{III} / \mathrm{II}}$ and $\mathrm{Fe}^{\mathrm{II} / \mathrm{I}}$ couples, $\mathrm{Fe}^{\mathrm{III} / \mathrm{II}} \mathrm{ET}$ kinetics, catalytic reduction of dioxygen, and evidence for water-free and water-bound forms of the iNOS heme based on scan rate and $\mathrm{pH}$ dependence data.

DDAB films were formed on BPG $\left(0.07 \mathrm{~cm}^{2}\right)$ by depositing $5 \mu \mathrm{L}$ of a $10 \mathrm{mM}$ aqueous solution of DDAB on the electrode surface, followed by slow drying overnight. iNOS was incorporated into the film by soaking the coated electrode in a solution of enzyme $(\sim 20 \mu \mathrm{M}$ in $50 \mathrm{mM}$ $\mathrm{KP}_{\mathrm{i}}, 50 \mathrm{mM} \mathrm{KCl}, \mathrm{pH} 7$ buffer) for 30 minutes. A voltammogram of iNOS in DDAB on BPG is shown in Figure 1. We have assigned $\mathrm{E}_{1}(-191 \mathrm{mV})$ and $\mathrm{E}_{2}(-1049 \mathrm{mV})$ to heme $\mathrm{Fe}^{\mathrm{III} / \mathrm{II}}$ and $\mathrm{Fe}^{\mathrm{II} / \mathrm{I}}$ couples, consistent with other studies of heme proteins in DDAB films. ${ }^{8,9}$ Notably, a couple similar to $\mathrm{E}_{2}$ was observed for neuronal nitric oxide synthase (nNOS), but was not assigned. ${ }^{7}$ Our assignments of $E_{1}$ and $E_{2}$ are supported by voltammetry in the presence of carbon monoxide: $\mathrm{E}_{1}$ shifts approximately $+62 \mathrm{mV}$ (consistent with other studies ${ }^{10,11}$ ), while $\mathrm{E}_{2}$ is not observed (presumably beyond the solvent window). For comparison, redox titrations of iNOS in its resting state (6-coordinate heme, low spin) conducted in solution yield a potential of $-544 \mathrm{mV}$ (vs. $\mathrm{Ag} / \mathrm{AgCl}$ ) for $\mathrm{Fe}$ III/II ${ }^{12}$ Empirically, potential shifts are usually observed for heme proteins in surfactant films; ${ }^{13}$ the hydrophobic film likely leads to partial heme dehydration, causing the positive potential shift. ${ }^{14}$

Besides CO, other molecules in solution also bind the heme. In the presence of $500 \mathrm{mM}$ imidazole, $\mathrm{E}_{1}$ shifts $+20 \mathrm{mV}$. When dioxygen is added, large catalytic reduction currents at the onset of $E_{1}$ are observed (Supporting Information, Figure $S 1$ ).

For $\mathrm{E}_{1}$, the peak current is linear with scan rate (surface bound) up to $16.7 \mathrm{~V} / \mathrm{s}$, after which it is linear with the square root of the scan rate (diffusive). ${ }^{15}$ This behavior is characteristic of thin film electrochemistry and indicates finite diffusion of the protein within the film. ${ }^{16}$ Thus, up to $16.7 \mathrm{~V} / \mathrm{s}$, we treated the redox system as surface-confined.

Closer inspection of Figure 1 reveals that the $\mathrm{E}_{1}$ cathodic wave is slightly broader than the other waves. Voltammetry at variable scan rates allowed us to resolve this peak into two distinct cathodic processes, $\mathrm{E}_{\mathrm{p}, \mathrm{c}}(1)$ and $\mathrm{E}_{\mathrm{p}, \mathrm{c}}(2)$. Figure $2 \mathrm{a}$ shows voltammograms recorded in $\mathrm{pH} 7$ buffer at different scan rates. At high and low scan rates ( 8 vs. $0.05 \mathrm{~V} / \mathrm{s}$ ) only one cathodic peak $\left(E_{p, c}(1) v s . E_{p, c}(2)\right)$ is present, while both cathodic processes are observed at intermediate $(1 \mathrm{~V} / \mathrm{s})$ scan rates. In addition to being scan rate dependent, these cathodic processes are also $\mathrm{pH}$ dependent. At pH 5 and $1 \mathrm{~V} / \mathrm{s}$ (Figure $2 \mathrm{~b}$ ), only one cathodic peak $\left(\mathrm{E}_{\mathrm{p}, \mathrm{c}}(1)\right)$ is present. Conversely, at $\mathrm{pH} 9$ two distinct cathodic peaks are visible at $1 \mathrm{~V} / \mathrm{s}$ (Figure 2c); in fact, at higher $\mathrm{pH}, \mathrm{E}_{\mathrm{p}, \mathrm{c}}(2)$ is even more prominent. Notably, during the first cathodic sweep $\mathrm{E}_{\mathrm{p}, \mathrm{c}}(2)$ predominates, while in subsequent cathodic sweeps both $\mathrm{E}_{\mathrm{p}, \mathrm{c}}(1)$ and $\mathrm{E}_{\mathrm{p}, \mathrm{c}}(2)$ are resolved.

This $\mathrm{pH}$ and scan rate dependence led us to believe that the iNOS heme axial water ligand is involved in an equilibrium that gives rise to $\mathrm{E}_{\mathrm{p}, \mathrm{c}}(1)$ and $\mathrm{E}_{\mathrm{p}, \mathrm{c}}(2)$ (Scheme 1). At pH 7 and $1 \mathrm{~V} /$ $\mathrm{s}$, the first cathodic sweep results in $\mathrm{E}_{\mathrm{p}, \mathrm{c}}(2)$ : this correlates with initial reduction of $\mathrm{Fe}^{\mathrm{III}}$ $\mathrm{OH}_{2}$. The lability of the $\mathrm{Fe}^{\mathrm{II}}-\mathrm{OH}_{2}$ bond results in rapid conversion to a 5-coordinate heme. 17,18 Oxidation of $\mathrm{Fe}^{\mathrm{II}}$ to $\mathrm{Fe}^{\mathrm{III}}$, followed by a second cathodic sweep at intermediate scan rates $(1 \mathrm{~V} / \mathrm{s}$, Figure 2a) gives rise to two reduction peaks, corresponding to reduction of water-free $\left(\mathrm{E}_{\mathrm{p}, \mathrm{c}}(1)\right)$ and water-bound $\left(\mathrm{E}_{\mathrm{p}, \mathrm{c}}(2)\right) \mathrm{Fe}^{\mathrm{III}}$ hemes. 
Our interpretation is supported by the following observations. First, $E_{p, c}(1)$ and $E_{p, c}(2)$ differ by approximately $133 \pm 9 \mathrm{mV}$, a value consistent with the potential difference between 5 - and 6-coordinate iNOS hemes. ${ }^{12}$ Second, voltammetry at low $\mathrm{pH}$ results in a single cathodic peak attributable to $\mathrm{E}_{\mathrm{p}, \mathrm{c}}(1)$. Under acidic conditions, disruption of hydrogen bonding in the heme pocket likely leads to dissociation of the axial water, resulting in a 5-coordinate heme. Third, voltammetry at high $\mathrm{pH}$ (Figure $2 \mathrm{c}$ ), where the axial water is partially deprotonated, shows that $E_{p, c}(2)$ is more prominent. Hydroxide will have greater affinity for the cationic metal center, thereby shifting the cathodic peak distribution further to $E_{p, c}(2)$. Fourth, voltammetry in the presence of imidazole yields a single cathodic process, consistent with constant heme ligation as it cycles between oxidation states (Figure S2). ${ }^{19}$

The dependence of the cathodic peak distribution on scan rate can be explained in terms of Scheme 1. At high scan rates, after oxidation of $\mathrm{Fe}^{\mathrm{II}}$, reduction of water-free $\mathrm{Fe}^{\mathrm{III}}$ occurs faster than water ligation to $\mathrm{Fe}^{\mathrm{III}}$, yielding only $\mathrm{E}_{\mathrm{p}, \mathrm{c}}(1)$. Conversely, scanning slow allows water enough time to ligate $\mathrm{Fe}^{\mathrm{III}}$ before reduction, shifting the cathodic peak distribution to $\mathrm{E}_{\mathrm{p}, \mathrm{c}}(2)$. Thus, intermediate scan rates yield both $\mathrm{E}_{\mathrm{p}, \mathrm{c}}(1)$ and $\mathrm{E}_{\mathrm{p}, \mathrm{c}}(2)$.

Using $\mathrm{E}_{\mathrm{B}, \mathrm{C}}(1), \mathrm{k}^{\circ}\left(\Delta \mathrm{G}^{\circ}=0\right)$ for $\mathrm{ET}$ to the 5-coordinate heme evaluated at $16.7 \mathrm{~V} / \mathrm{s}$ and $\mathrm{pH} 7$ is $370 \mathrm{~s}^{-1} .20$ With this value, we used digital simulation to effectively model the experimental results in Figure 2a (see Supporting Information). From the simulation, we estimated values for $\boldsymbol{k}_{1}, \boldsymbol{k}_{2}$, and $\boldsymbol{k}_{3}$ in Scheme 1 to be $1 \mathrm{~s}^{-1}, 0.5 \mathrm{~s}^{-1}$, and $>100 \mathrm{~s}^{-1}$. As expected, ${ }^{17,18}$ water dissociation from $\mathrm{Fe}^{\mathrm{II}}$ is rapid $\left(\boldsymbol{k}_{3}\right)$, while the kinetics of the $\mathrm{Fe}^{\mathrm{III}}$ equilibrium with water $\left(\boldsymbol{k}_{\boldsymbol{l}}\right.$, $\boldsymbol{k}_{2}$ ) appear slow. In the catalytic cycle of iNOS, the first ET event is proposed to be the ratelimiting step for substrate turnover, occurring at $1 \mathrm{~s}^{-1} \cdot{ }^{21} \mathrm{k}^{\circ}$ for the 5 -coordinate heme indicates that well-coupled pathways do exist between the protein surface and the heme; thus, electron tunneling is unlikely to be rate-limiting in catalysis. Rather, our simulation suggests that water dissociation from $\mathrm{Fe}^{\mathrm{III}}$ may function as a potential gating mechanism for the catalytic cycle. 22

Proton-coupled ET was observed for nNOS in DDAB films as demonstrated by the variation of $\mathrm{E}_{1 / 2}$ with $\mathrm{pH} .{ }^{7}$ For comparison, we performed voltammetry on iNOS at $200 \mathrm{mV} / \mathrm{s}$ and plotted the variation of $\mathrm{E}_{1 / 2}$ with $\mathrm{pH}$ for $\mathrm{E}_{1}$ (Figure $2 \mathrm{~d}$ ). ${ }^{23}$ The data reveal no variation of $\mathrm{E}_{1 / 2}$ for $\mathrm{pH}$ $<5$, implying simple conversion of 5-coordinate $\mathrm{Fe}^{\mathrm{III}}$ to $\mathrm{Fe}^{\mathrm{II}}$. At $\mathrm{pH}>7, \mathrm{E}_{1 / 2}$ varies linearly with $\mathrm{pH}$ according to $-53 \mathrm{mV} / \mathrm{pH}$ unit, as is often found for heme proteins. ${ }^{24,25}$ The observation of proton-coupled ET in a $\mathrm{pH}$ range where the heme is water-ligated further indicates that the heme axial water ligand gates ET in iNOS.

\section{Supplementary Material}

Refer to Web version on PubMed Central for supplementary material.

\section{Acknowledgements}

We thank NSERC (Canada) (AKU), HHMI (AKU), NIH (DK19038 to HBG, GM070868 to DBG), the David and Lucille Packard Foundation (MGH) and the Parsons Foundation (WBB) for research support; S. Luzzi (U.C. Berkeley) for assistance with protein expression and purification.

\section{References}

1. Culotta E, Koshland DE. Science 1992;258:1862-1865. [PubMed: 1361684]

2. Alderton WK, Cooper CE, Knowles RG. Biochemical J 2001;357:593-615.

3. Aktan F. Life Sciences 2003;75:639-657. [PubMed: 15172174]

4. Hurshman AR, Krebs C, Edmondson DE, Marletta MA. Biochemistry 2003;42:13287-13303. [PubMed: 14609340] 
5. Rusling JF. Acc Chem Res 1998;31:363-369.

6. Studies have shown that heme proteins retain their solution spectroscopic properties within surfactant films: see, for example, Ma H, Hu N. Anal Lett 2001;34:339-361.Rusling JF, Nassar AF. J Am Chem Soc 1993;115:11891-11897.

7. Direct electrochemistry of the neuronal nitric oxide synthase heme domain utilizing the surfactant film methodology has been reported (Bayachou M, Boutros JA. J Am Chem Soc 2004;126:12722. [PubMed: 15469236]

8. Immoos CE, Chou J, Bayachou M, Blair E, Greaves J, Farmer PJ. J Am Chem Soc 2004;126:49344942. [PubMed: 15080699]

9. Ma H, Hu N. Anal Lett 2001;34:339-361.

10. Zhang Z, Nassar AE, Lu Z, Schenkman JB, Rusling JF. J Chem Soc, Faraday Trans 1997;93:1769_ 1774.

11. Fleming BD, Tian Y, Bell SG, Wong L, Urlacher V, Hill HAO. Eur J Biochem 2003;270:4082-4088. [PubMed: 14519119]

12. Presta A, Weber-Main AM, Stankovich MT, Stuehr DJ. J Am Chem Soc 1998;120:9460-9465.

13. Lvov YM, Lu Z, Schenkman JB, Zu X, Rusling JF. J Am Chem Soc 1998;120:4073-4080.

14. Tezcan FA, Winkler JR, Gray HB. J Am Chem Soc 1998;120:13383-13388.

15. Bard, AJ.; Faulkner, LR. Electrochemical Methods. 2. John Wiley \& Sons, Inc; New York: 2001.

16. Lin R, Immoos CE, Farmer PJ. J Biol Inorg Chem 2000;5:738-747. [PubMed: 11129001]

17. Wilker JJ, Dmochowski IJ, Dawson JH, Winkler JR, Gray HB. Angew Chem Int Ed 1999;38:90-92.

18. Crutchley RJ, Ellis WR, Gray HB. J Am Chem Soc 1985;107:5002-5004.

19. Dawson JH, Andersson LA, Sono M. J Biol Chem 1983;258:13637-13645. [PubMed: 6643443]

20. Laviron E. J Electroanal Chem 1979;101:19-28.

21. Presta A, Siddhanta U, Wu C, Sennequier N, Huang L, Abu-Soud HM, Erzurum S, Stuehr DJ. Biochemistry 1998;37:298-310. [PubMed: 9425051]

22. See Armstrong FA. J Chem Soc Dalton Trans 2002:661-671.for a discussion of gated ET in proteins

23. At $200 \mathrm{mV} / \mathrm{s}$, the two cathodic peaks in $\mathrm{E}_{1}$ collapse into a single peak, yielding a potential representative of the population distribution between $\mathrm{E}_{\mathrm{p}, \mathrm{c}}(1)$ and $\mathrm{E}_{\mathrm{p}, \mathrm{c}}(2)$ and permitting us to estimate a midpoint potential $\left(\mathrm{E}_{1 / 2}\right)$ for $\mathrm{E}_{1}$.

24. Munge B, Estavillo C, Schenkman JB, Rusling JF. ChemBioChem 2003;4:82-89. [PubMed: 12512080]

25. Aguey-Zinsou K, Bernhardt PV, Voss JJD, Slessor KE. Chem Commun 2003:418-419. 


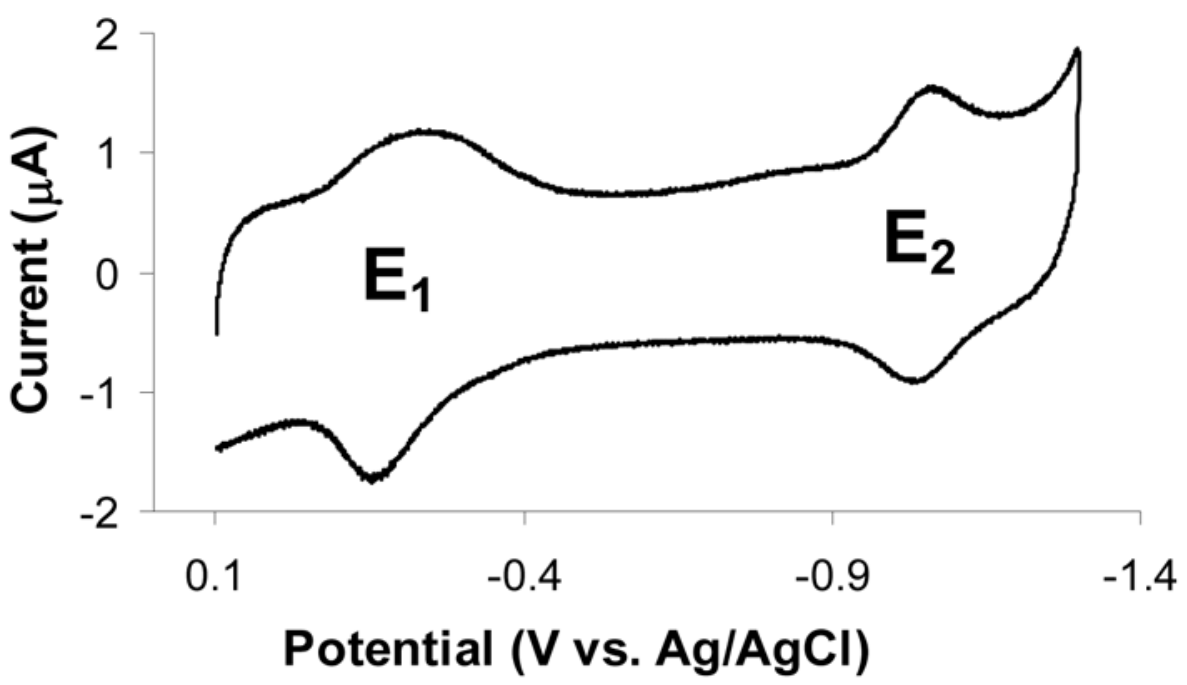

Figure 1.

Cyclic voltammogram of iNOS in DDAB on BPG $\left(0.07 \mathrm{~cm}^{2}\right)$ at $200 \mathrm{mV} / \mathrm{s}$ in $50 \mathrm{mM} \mathrm{KP} / 50$ $\mathrm{mM} \mathrm{KCl} / \mathrm{pH} 7$. 

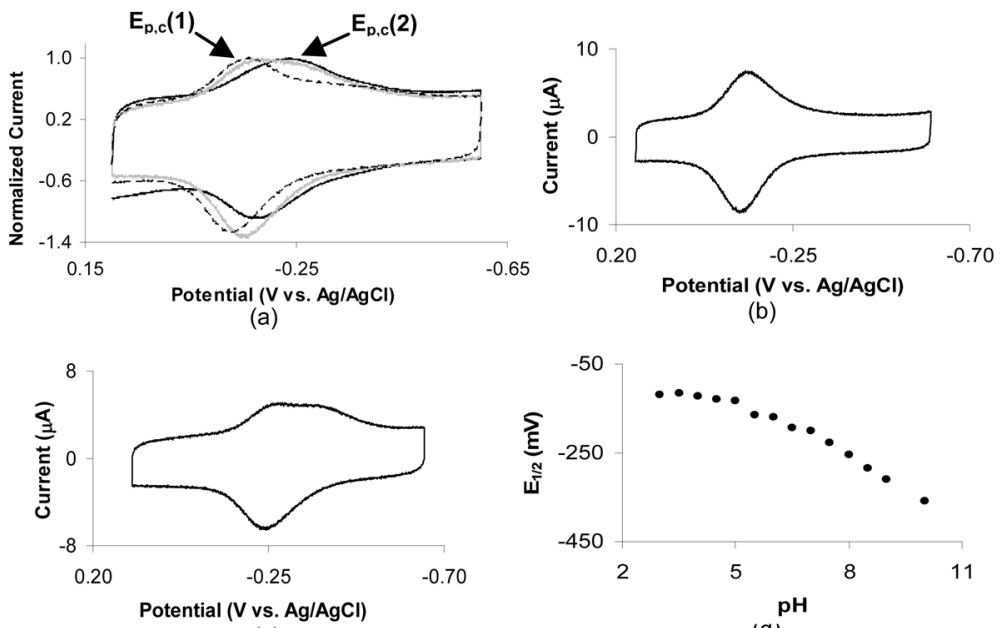

(c)

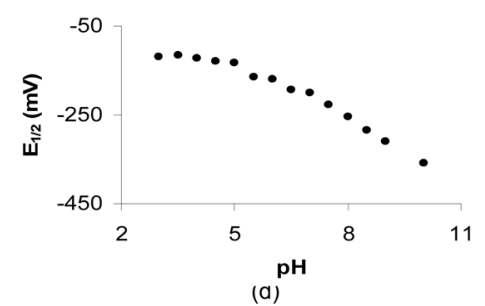

Figure 2.

Cyclic voltammograms of iNOS in DDAB on BPG in $50 \mathrm{mM} \mathrm{KP} / 50 \mathrm{mM} \mathrm{KCl}$ a) at 0.05 (black), 1 (gray), and 8 (dashed) V/s, $\mathrm{pH} 7$; b) at $1 \mathrm{~V} / \mathrm{s}, \mathrm{pH} 5$; c) at $1 \mathrm{~V} / \mathrm{s}, \mathrm{pH} 9$. d) Variation of the average $\mathrm{Fe}^{\mathrm{III} / \mathrm{II}}$ midpoint potential with $\mathrm{pH}$ at $200 \mathrm{mV} / \mathrm{s}$. 

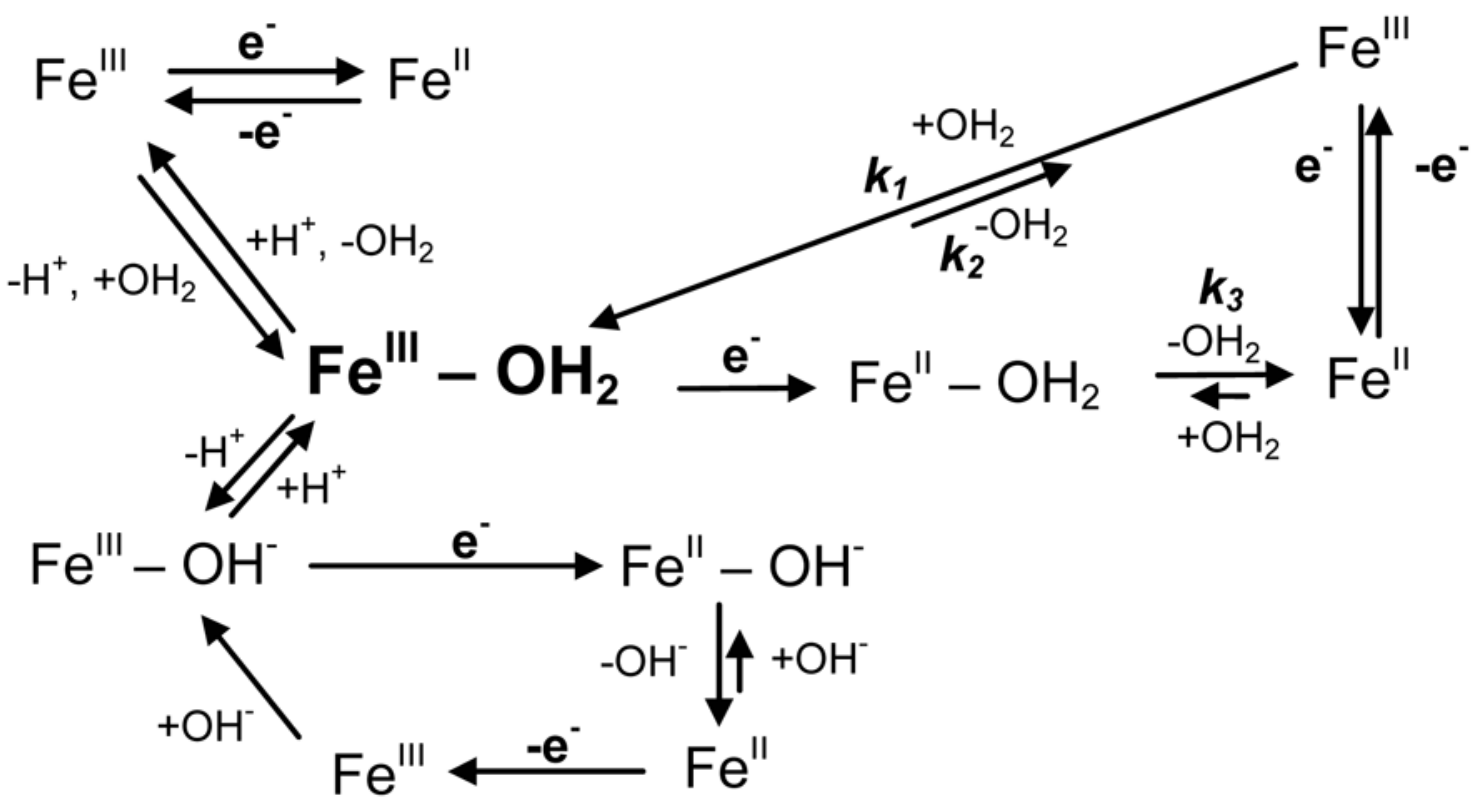

Scheme 1. 